\title{
PENERAPAN METODE ANALYTICAL HIERARCHY PROCESS (AHP) DAN SIMPLE ADDITEVE WEIGHTING (SAW) DALAM SISTEM PENDUKUNG KEPUTUSAN PEMILIHAN BIBIT CABAI MERAH UNGGUL
}

\author{
Usep Saprudin \\ Institut Informasi dan Bisnis (IIB) Darmajaya \\ Jl. ZA. Pagar Alam No.93, Gedong Meneng, Kec. Rajabasa, \\ Kota Bandar Lampung, Lampung 35141 \\ usepkreatif@gmail.com
}

\begin{abstract}
Abstrak
Cabai Merah di Indonesia adalah salah satu komoditas hortikultura yang banyak dibudidayakan oleh petani, karena selain memiliki beberapa manfaat kesehatan cabai merah juga mempunyai harga jual yang tinggi. Banyaknya jenis Cabai Merah terkadang membuat para petani bingung untuk memilih bibit yang cocok dan sesuai untuk tanahnya terutama petani yang belum berpengalaman. Terlebih lagi virus dan bakteri Cabai Merah yang beranekaragam menjadi salah satu kebimbangan para petani untuk memilih bibit yang sesuai dan tidak mengalami kerugian saat panen. Dalam sistem pendukung keputusan ini, digunakan penggabungan metode Analytical Hierarchy Process (AHP) dan Simple Additeve Weighting (SAW) untuk menentukan alternatif terbaik dari bibit cabai merah yang akan dipilih. Empat kriteria dasar yang digunakan yakni rekomendasi dataran, ketahanan penyakit, umur panen dan potensi panen. Metode AHP digunakan untuk menghitung bobot dari setiap kriteria yang kemudian di hitung menggunakan metode SAW untuk menghasilkan alternatif terbaik. Sistem Pendukung Keputusan ini diharapkan mampu memberikan bantuan dan rekomendasi alternatif terbaik kepada petani dalam memilih bibit cabai merah unggul yang sesuai dengan kebutuhan.
\end{abstract}

Kata kunci: Bibit cabai merah, Sistem Pendukung Keputusan, AHP dan SAW.

\section{Pendahuluan}

\subsection{Latar Belakang}

Di Indonesia Cabai Merah adalah salah satu komoditas hortikultura yang banyak dibudidayakan oleh petani, karena selain memiliki beberapa manfaat kesehatan cabai merah juga mempunyai harga jual yang tinggi. Salah satunya berfungsi dalam mengendalikan kanker karena kandungan lasparaginase dan capcaicin didalamnya. Selain itu kandungan vitamin $\mathrm{C}$ yang cukup tinggi pada Cabai Merah dapat memenuhi kebutuhan harian setiap orang, dan untuk menghindari nyeri lambung harus dikonsumsi secukupnya (Prajnanta, 2001). Cabai merah selain menjadi tenar sebagai bumbu masak, juga biasa digunakan sebagai bahan campuran.

Bagi masyarakat Indonesia usaha bercocok tanam Cabai Merah masih sangat menguntungkan. Tercatat pada kisaran $3 \mathrm{~kg} / \mathrm{kapita} / \mathrm{tahun}$ kebutuhan masyarakat Indonesia akan Cabai Merah. Oleh sebab itu banyak petani Cabai Merah di seluruh Indonesia dengan beragam jenis Cabai Merah yang di tanam. Banyak sekali pilihan bibit Cabai Merah yang menunjang petani Cabai Merah untuk bercocok tanam. Hingga kini telah dikenal lebih dari 12 jenis Cabai Merah. Namun demikian, yang banyak dibududayakan oleh petani cabai hanya beberapa saja, yakni: Cabai Merah rawit, Cabai Merah merah, paprika, dan Cabai Merah hias. Cabai Merah rawit terdiri dari Cabai Merah rawit putih,
Cabai Merah rawit jengki, dan Cabai Merah rawit jemprit (Tjahjadi, 1991).

Banyaknya jenis Cabai Merah terkadang membuat para petani bingung untuk memilih bibit yang cocok dan sesuai untuk tanahnya terutama petani yang belum berpengalaman. Terlebih lagi virus dan bakteri Cabai Merah yang beranekaragam menjadi salah satu kebimbangan para petani untuk memilih bibit yang sesuai dan tidak mengalami kerugian saat panen.

Dari latar belakang di atas, dapat di tarik kesimpulan perlu adanya sebuah sistem pendukung keputusan untuk membantu para petani Cabai Merah dalam memilih bibit Cabai Merah yang sesuai. Metode yang digunakan dalam pengambilan keputusan pemilihan bibit Cabai Merah ini adalah penggabungan dari Analytical Hierarchy Process (AHP) dan Simple Additeve Weighting (SAW). AHP merupakan salah satu metode multiple-criteria decision-making (MCDM). Metode ini dipilih karena telah banyak digunakan dan diterima secara luas di berbagai organisasi, perusahaan dan negara di seluruh dunia. AHP dibandingkan dengan metode lain hasilnya lebih konsisten serta sistem yang menerapkan metode Analytical Hierarchy Process lebih mudah dipahami dan digunakan. Sedangkan Metode SAW sering dikenal dengan istilah metode penjumlahan terbobot. Konsep dasar metode SAW adalah mencari penjumlahan terbobot dari rating kinerja pada setiap alternatif pada semua atribut. Metode SAW dapat membantu dalam pengambilan 
keputusan suatu kasus. Metode SAW ini lebih efisien karena waktu yang dibutuhkan dalam perhitungan lebih singkat. Oleh karena itu dengan menggabungkan kelebihan dari dua metode tersebut, diharapkan dapat membantu para petani dalam proses pengambilan keputusan pemilihan bibit Cabai Merah unggul.

\subsection{Rumusan Masalah}

Berdasarkan latar belakang yang telah dikemukakan di atas, maka dapat dibuat sebuah rumusan masalah yaitu "Bagaimana menerapkan penggabungan metode Analytical Hierarchy Process (AHP) dan Simple Additeve Weighting (SAW) dalam Sistem Pendukung Keputusan Pemilihan Bibit Cabai Merah Unggul."

\subsection{Batasan Masalah}

1. Sistem pendukung keputusan hanya sebagai alat bantu dalam menentukan keputusan dalam pemilihan bibit Cabai Merah unggul, tetapi keputusan terakhir tetap berada pada pihak petani Cabai Merah.

2. Kriteria yang digunakan dalam sistem pendukung keputusan ini antara lain Rekomendasi Dataran, Ketahanan Penyakit, Umur Panen, Potensi Panen.

3. Alternatif yang digunakan adalah jenis-jenis Cabai Merah Unggul antara lain : KASTILO F1, LADO F1, LARIS F1, LABA F1, LAJU F1, LENTUR F1, PM 999 F1, TARO F1

4. Pengolahan data pada penelitian ini dilakukan dengan menggunakan metode Analytical Hierarchy Process (AHP) dan Simple Additeve Weighting (SAW).

\subsection{Tujuan Penelitian}

Adapun tujuan dari penelitian ini adalah Menerapkan penggabungan metode AHP dan metode SAW dalam sistem pendukung keputusan pemilihan Bibit Cabai Merah Unggul.

\subsection{Manfaat Penelitian}

Manfaat yang diharapkan dapat diperoleh dari tulisan ini yaitu, membantu para petani cabai merah dalam menentukan pilihan bibit cabai merah unggul yang sesuai dengan kebutuhan.

\section{Metode Penelitian}

\subsection{Pengumulan Data}

1. Metode awancara

Proses memperoleh keterangan dengan cara tanya jawab sambil bertatap muka antara pewawancara dengan petani cabai merah Pekalongan Lampung Timur dan memberikan data yang berkaitan dengan masalah yang diteliti. Responden dari petani cabai merah berjumlah 35 orang. Pewawancara menggunakan daftar pertanyaan yang berkaitan dengan tujuan penelitian. Daftar tersebut diberikan kepada petani cabai merah dengan harapan mereka akan memberikan tanggapan terhadap daftar pertanyaan tersebut.

\section{Metode Observasi}

Pengumpulan data yang dilakukan dengan cara mengamati secara langsung pada obyek penelitian tentang bagaimana respon petani cabai merah dalam memilih bibit cabai merah.

\section{Metode Kepustakaan}

Pengumpulan data yang berasal dari buku, jurnal, laporan serta sumber informasi tertulis lainnya yang terkait dengan masalah yang diteliti.

\subsection{Kerangka Penelitian}

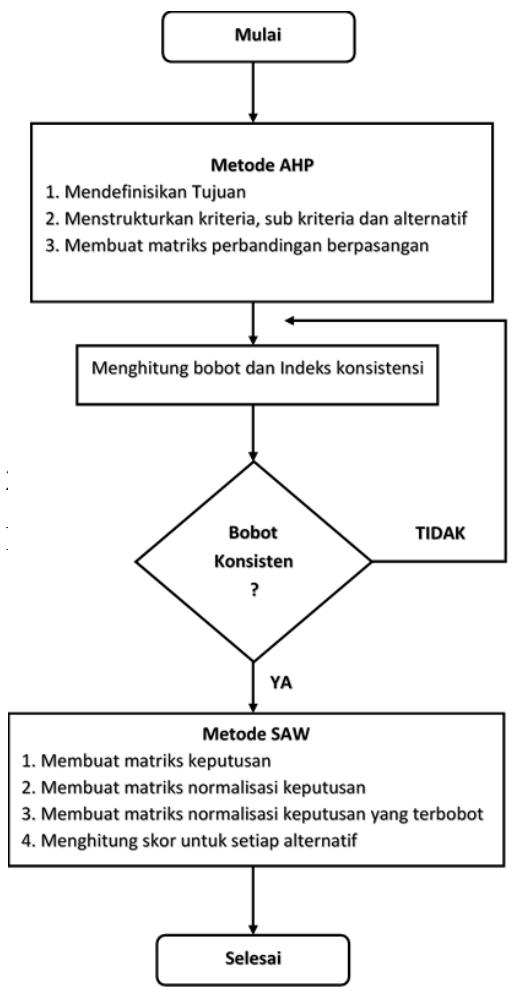

ini dimulai dengan Mendefinisikan Tujuan, Menstrukturkan kriteria, sub kriteria dan alternative. Lalu Membuat matriks perbandingan berpasangan dan kemudian Menghitung bobot dan Indeks konsistensi menggunakan prinsip dasar Analytical Hierarchy Process (AHP) berdasarkan data yang dihasilkan dari wawancara.

Hasil dari bobot yang telah di hitung menggunakan prinsip AHP tahap selanjutnya diproses menggunakan prinsip dasar Simple Additeve Weighting (SAW) dengan urutan:

1. Membuat matriks keputusan

2. Membuat matriks normalisasi keputusan

3. Membuat matriks normalisasi keputusan yang terbobot 
4. Menghitung skor untuk setiap alternatif

\section{Hasil Dan Pembahasan}

Langkah-langkah dari implementasi dan pembahasan dari hasil penelitian yang telah dilakukan tentang penggabungan metode Analytical Hierarchy Process (AHP) dan Simple Additeve Weighting (SAW) dalam Sistem Pendukung Keputusan Pemilihan Bibit Cabai Merah Unggul.

\subsection{Penghitungan Menggunakan Metode AHP}

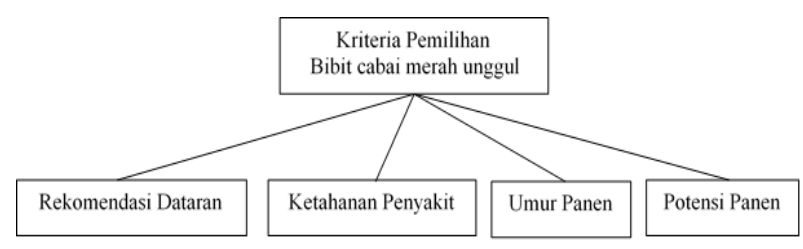

Hierarki Pemilihan Bibit Cabai Merah Unggul

Tabel 1. Matriks Perbandingan Berpasangan

\begin{tabular}{|l|c|c|c|c|}
\hline \multicolumn{1}{|c|}{ Kriteria } & $\begin{array}{c}\text { Rekomendasi } \\
\text { Dataran }\end{array}$ & $\begin{array}{c}\text { Ketahanan } \\
\text { Penyakit }\end{array}$ & $\begin{array}{c}\text { Umur } \\
\text { Panen }\end{array}$ & $\begin{array}{c}\text { Potensi } \\
\text { Panen }\end{array}$ \\
\hline $\begin{array}{l}\text { Rekomendasi } \\
\text { Dataran }\end{array}$ & $\mathbf{1}$ & $1 / 5$ & $1 / 7$ & $1 / 2$ \\
\hline $\begin{array}{l}\text { Ketahanan } \\
\text { Penyakit }\end{array}$ & 5 & $\mathbf{1}$ & 2 & 52. \\
\hline Umur Panen & 7 & $1 / 5$ & $\mathbf{1}$ & 7 \\
\hline Potensi Panen & 2 & $1 / 2$ & $1 / 7$ & $\mathbf{1}$ \\
\hline
\end{tabular}

1. Normalisasi Matriks

a. Menjumlahkan nilai dari setiap kolom pada matriks perbandingan berpasangan yang ditunjukkan pada persamaan berikut ini. (Fitriyani, 2017)

$$
n=\sum_{i}^{Z}=0^{x_{i j}}
$$

Keterangan:

$\mathrm{n}=$ hasil penjumlahan tiap kolom

$\mathrm{z}=$ banyak alternatif

$\mathrm{I}=1,2,3 \ldots, \mathrm{z}$

$\mathrm{x}=$ nilai tiap cell / gabungan antara kolom dan baris

$\mathrm{n}=1+5+7+2=\mathbf{1 5} \ldots \mathrm{dst}$

Hasil penjumlahan nilai dari setiap kolom pada matriks perbandingan berpasangan:

Tabel 2. Penjumlahan Matriks

\begin{tabular}{|l|c|c|c|c|}
\hline \multicolumn{1}{|c|}{ Kriteria } & $\begin{array}{c}\text { Rekomendasi } \\
\text { Dataran }\end{array}$ & $\begin{array}{c}\text { Ketahanan } \\
\text { Penyakit }\end{array}$ & $\begin{array}{c}\text { Umur } \\
\text { Panen }\end{array}$ & $\begin{array}{c}\text { Potensi } \\
\text { Panen }\end{array}$ \\
\hline $\begin{array}{l}\text { Rekomendasi } \\
\text { Dataran }\end{array}$ & $\mathbf{1}$ & 0,20 & 0,14 & 0,50 \\
\hline $\begin{array}{l}\text { Ketahanan } \\
\text { Penyakit }\end{array}$ & 5 & $\mathbf{1}$ & 2 & 5 \\
\hline Umur Panen & 7 & 0,50 & $\mathbf{1}$ & 7 \\
\hline $\begin{array}{l}\text { Potensi } \\
\text { Panen }\end{array}$ & 2 & 0,20 & 0,14 & $\mathbf{1}$ \\
\hline \multicolumn{1}{c|}{$\mathrm{N}$} & 15 & 1,90 & 3,29 & 14 \\
\hline
\end{tabular}

b. Membagi setiap nilai kolom dengan total kolom yang bersangkutan untuk memperoleh normalisasi matriks yang ditunjukkan pada persamaan dibawah ini. (P. Diah, 2018)

$$
m=\frac{x_{i j}}{n}
$$

Keterangan:

$\mathrm{m}=$ hasil normalisasi

$\mathrm{x}=$ nilai tiap cell / gabungan antara baris dan kolom

$$
\mathrm{n}=\text { hasil jumlah tiap kolom }
$$$$
\mathrm{m}=\frac{1}{15}=\mathbf{0 , 0 6 7} \ldots . . \mathrm{dst}
$$

\begin{tabular}{|c|c|c|c|c|}
\hline $\begin{array}{c}\text { KRITERI } \\
\text { A }\end{array}$ & $\begin{array}{l}\text { Rekomend } \\
\text { asi Dataran }\end{array}$ & $\begin{array}{c}\text { Ketahanan } \\
\text { Penyakit }\end{array}$ & $\begin{array}{l}\text { Umur } \\
\text { Panen }\end{array}$ & $\begin{array}{l}\text { Potensi } \\
\text { Panen }\end{array}$ \\
\hline $\begin{array}{l}\text { Rekomend } \\
\text { asi Dataran }\end{array}$ & 0,067 & 0,105 & 0,043 & 0,037 \\
\hline $\begin{array}{l}\text { Ketahanan } \\
\text { Penyakit }\end{array}$ & 0,333 & 0,526 & 0,609 & 0,370 \\
\hline $\begin{array}{l}\text { Umur } \\
\text { Panen }\end{array}$ & 0,467 & 0,263 & 0,304 & 0,519 \\
\hline \begin{tabular}{|l|}
$\begin{array}{l}\text { Potensi } \\
\text { Panen }\end{array}$ \\
\end{tabular} & 0,133 & 0,105 & 0,043 & 0,074 \\
\hline $\begin{array}{l}\text { Menghitur } \\
\text { Menjumla } \\
\text { elembagi } \\
\text { prioritas }\end{array}$ & $\begin{array}{l}\text { nilai bol } \\
\text { san nil } \\
\text { sil jumla }\end{array}$ & $\begin{array}{l}\text { priorit } \\
\text {-nilai } \\
\text { yya deng }\end{array}$ & $\begin{array}{l}\text { i ba } \\
\text { banya } \\
\text { ata-ra } \\
\text { pers }\end{array}$ & $\begin{array}{l}\text { dan } \\
\text { mlah } \\
\text { obot } \\
\text { n di }\end{array}$ \\
\hline
\end{tabular}

Hasil nilai normalisasi matriks:

Tabel 3. Normalisasi Matriks

$$
b p=\frac{\sum_{j}^{n}=0 x^{i j}}{n}
$$

Keterangan :

$\mathrm{bp}=$ hasil rata-rata/bobot prioritas

$\mathrm{n}=$ banyak kriteria

$\mathrm{j}=1,2,3 \ldots, \mathrm{n}$

$\mathrm{x}=$ nilai tiap cell / gabungan antara baris dan kolom

$$
\begin{aligned}
b p & =\frac{0,067+0,105+0,043+0,037}{4} \\
& =\mathbf{0 , 0 6 3} \ldots . . \mathrm{dst}
\end{aligned}
$$

Hasil dari penjumlahan baris dan di bagi dengan jumlah elemen/ jumlah kriteria

Tabel 4. Bobot Prioritas

\begin{tabular}{|l|c|}
\hline \multicolumn{1}{|c|}{ KRITERIA } & Bobot \\
\hline Rekomendasi Dataran & 0,063 \\
\hline Ketahanan Penyakit & 0,460 \\
\hline Umur Panen & 0,388 \\
\hline Potensi Panen & 0,089 \\
\hline \multicolumn{1}{|c|}{ N } & 1 \\
\hline
\end{tabular}

3. Menghitung Eign Maksimum

a. Kalikan setiap nilai cell pertama dengan bobot prioritas pertama, nilai pada kolom cell kedua dengan prioritas kedua, dan seterusnya. 
Kolom Rekomendasi Dataran: 1 x 0,063= $\mathbf{0 , 0 6 3} \ldots$...dst

Tabel 5. Perkalian Setiap Nilai Cell Dengan Bobot Prioritas

\begin{tabular}{|l|c|c|c|c|}
\hline KRITERIA & $\begin{array}{c}\text { Rekomen } \\
\text { dasi } \\
\text { Dataran }\end{array}$ & $\begin{array}{c}\text { Ketahana } \\
\mathrm{n} \\
\text { Penyakit }\end{array}$ & $\begin{array}{c}\text { Umur } \\
\text { Panen }\end{array}$ & $\begin{array}{c}\text { Poten } \\
\text { si } \\
\text { Panen }\end{array}$ \\
\hline $\begin{array}{l}\text { Rekomenda } \\
\text { si Dataran }\end{array}$ & 0,063 & 0,092 & 0,055 & 0,045 \\
\hline $\begin{array}{l}\text { Ketahanan } \\
\text { Penyakit }\end{array}$ & 0,316 & 0,460 & 0,776 & 0,445 \\
\hline $\begin{array}{l}\text { Umur } \\
\text { Panen }\end{array}$ & 0,442 & 0,230 & 0,388 & 0,623 \\
\hline $\begin{array}{l}\text { Potensi } \\
\text { Panen }\end{array}$ & 0,126 & 0,092 & 0,055 & 0,089 \\
\hline
\end{tabular}

b. Jumlahkan hasilnya untuk setiap baris pada matriks.

Baris Rekomendasi Dataran: 0,063 + 0,092 $+0,055+0,045=\mathbf{0 , 2 5 5} \ldots \mathrm{dst}$

Tabel 6. Hasil Penjumlahan Setiap Baris

\begin{tabular}{|l|c|c|c|c|c|}
\hline $\begin{array}{l}\text { KRITER } \\
\text { IA }\end{array}$ & $\begin{array}{c}\text { Rekom } \\
\text { endasi } \\
\text { Datara } \\
\mathrm{n}\end{array}$ & $\begin{array}{c}\text { Ketahana } \\
\mathrm{n} \\
\text { Penyakit }\end{array}$ & $\begin{array}{c}\text { Umur } \\
\text { Pane } \\
\mathrm{n}\end{array}$ & $\begin{array}{c}\text { Poten } \\
\text { si } \\
\text { Pane } \\
\mathrm{n}\end{array}$ & $\begin{array}{c}\text { Jumla } \\
\mathrm{h}\end{array}$ \\
\hline $\begin{array}{l}\text { Rekomen } \\
\text { dasi } \\
\text { Dataran }\end{array}$ & 0,063 & 0,092 & 0,055 & 0,045 & 0,255 \\
\hline $\begin{array}{l}\text { Ketahana } \\
\mathrm{n} \\
\text { Penyakit }\end{array}$ & 0,316 & 0,460 & 0,776 & 0,445 & 1,997 \\
\hline $\begin{array}{l}\text { Umur } \\
\text { Panen }\end{array}$ & 0,442 & 0,230 & 0,388 & 0,623 & 1,683 \\
\hline $\begin{array}{l}\text { Potensi } \\
\text { Panen }\end{array}$ & 0,126 & 0,092 & 0,055 & 0,089 & 0,363 \\
\hline
\end{tabular}

c. Hasil dari penjumlahan baris dibagi dengan elemen prioritas yang bersangkutan.

Baris Rekomendasi Dataran: 0,255/0,063 = 4,041 ...dst

Tabel 7. Hasil Penjumlahan Baris Dibagi Dengan Elemen Prioritas Baris

\begin{tabular}{|l|c|c|c|}
\hline \multicolumn{1}{|c|}{ KRITERIA } & $\begin{array}{c}\text { Jumlah } \\
\text { Baris }\end{array}$ & $\begin{array}{c}\text { bobot } \\
\text { Prioritas }\end{array}$ & $\lambda$ \\
\hline $\begin{array}{l}\text { Rekomendasi } \\
\text { Dataran }\end{array}$ & 0,255 & 0,063 & 4,041 \\
\hline $\begin{array}{l}\text { Ketahanan } \\
\text { Penyakit }\end{array}$ & 1,997 & 0,460 & 4,344 \\
\hline Umur Panen & 1,683 & 0,388 & 4,336 \\
\hline Potensi Panen & 0,363 & 0,089 & 4,073 \\
\hline
\end{tabular}

d. Jumlahkan hasil lamda tiap kriteria dibagi dengan banyak elemen yang ada, hasilnya disebut $\lambda$ maks yang ditunjukkan pada persamaan dibawah ini. (N. N. Satriani, 2018)

$$
\lambda_{\text {maks }}=\frac{\sum \lambda}{n}
$$

Keterangan:

$\lambda$ maks $=$ eigen maksimum

$\mathrm{n} \quad=$ banyak kriteria

$$
\lambda_{\text {maks }}=\frac{4,041+4,344+4,336+4,073}{4}
$$

4. Menghitung Indeks Konsistensi atau Consistency Index (CI) yang ditunjukkan pada persamaan dibawah ini. (D. Walangare, 2012)

$$
C I=\frac{\lambda_{m a k s}-n}{n-1}
$$

Keterangan:

$$
\mathrm{n}=\text { banyak elemen }
$$

$$
C I=\frac{4,198-4}{4-1}=0,066
$$

5. Menghitung Rasio Konsistensi atau Consistency Ratio (CR) yang ditunjukkan pada persamaan dibawah ini. (Munthafa, 2017)

$$
\begin{aligned}
& C R=\frac{C I}{R I} \\
& \text { Keterangan: } \\
& \mathrm{RI}=\text { rasio indeks } \\
& \mathrm{CR}=\text { rasio konsistensi } \\
& \text { Nilai RI dapat dilihat ditabel }
\end{aligned}
$$

Tabel 8. Nilai Index Random

\begin{tabular}{|c|c|c|c|}
\hline $\begin{array}{c}\text { Ukuran } \\
\text { Matriks } \\
(\mathrm{N})\end{array}$ & Nilai RI & $\begin{array}{c}\text { Ukuran } \\
\text { Matriks (N) }\end{array}$ & Nilai RI \\
\hline 1,2 & 0 & 9 & 1,45 \\
\hline 3 & 0,58 & 10 & 1,49 \\
\hline 4 & 0,90 & 11 & 1,51 \\
\hline 5 & 1,12 & 12 & 1,48 \\
\hline 6 & 1,24 & 13 & 1,56 \\
\hline 7 & 1,32 & 14 & 1,57 \\
\hline 8 & 1,41 & 15 & 1,59 \\
\hline
\end{tabular}

$$
C R=\frac{0,066}{0,90}=0,07
$$

8. Memeriksa konsistensi hirarki jika nilai $\mathrm{CR}>0,1$ maka penilaian data judgement tidak konsisten dan harus diperbaiki. Jika rasio konsisten CR 0,1 maka perhitungan data konsisten dan benar.

$\mathrm{CR}(0.07) \leq 0.1$ maka perhitungan data konsisten dan benar.

\subsection{Penghitungan Menggunakan Metode SAW}

Metode SAW yaitu menentukan nilai bobot pada setiap atributnya, kemudian pada tahap selanjutnya 
dilakukan perengkingan yang akan menyeleksi alternatif terbaik. Dalam penelitian ini metode SAW digunakan untuk perhitungan terakhir atau menentukan jenis dan merek bibit cabai merah unggul yang dibutuhkan petani.

Tahap-tahap dalam penyelesaian metode SAW menurut (Frieyadie, 2016) adalah:

1. Menentukan kriteria-kriteria yang dijadikan acuan dalam pendukung keputusan yaitu $\mathrm{Ci}$.

Tabel 9. Rekomendasi Dataran

\begin{tabular}{|c|l|l|}
\hline Kriteria & \multicolumn{1}{|c|}{ Range } & \multicolumn{1}{c|}{ Bobot } \\
\hline \multirow{5}{*}{$\begin{array}{c}\text { Rekomendasi } \\
\text { Dataran }\end{array}$} & $\begin{array}{l}\text { Dataran } \\
\text { Rendah }\end{array}$ & Variabel ke-1 / 1/4 =0,25 \\
\cline { 2 - 3 } & $\begin{array}{l}\text { Dataran } \\
\text { Menengah }\end{array}$ & Variabel ke-2 / 2/4 =0,5 \\
\cline { 2 - 3 } & $\begin{array}{l}\text { Dataran } \\
\text { Rendah s.d } \\
\text { menengah }\end{array}$ & Variabel ke-3 / 3/4 =0,75 \\
\cline { 2 - 3 } & $\begin{array}{l}\text { Dataran } \\
\text { rendah s.d } \\
\text { tinggi }\end{array}$ & Variabel ke-4 / 4/4 =1 \\
\hline
\end{tabular}

Tabel 10. Ketahanan Penyakit

\begin{tabular}{|c|l|l|}
\hline Kriteria & \multicolumn{1}{|c|}{ Range } & \multicolumn{1}{c|}{ Bobot } \\
\hline \multirow{5}{*}{$\begin{array}{c}\text { Ketahanan } \\
\text { Penyakit }\end{array}$} & $\begin{array}{l}\text { Tidak tahan } \\
\text { penyakit }\end{array}$ & Variabel ke-1 / 1/5 =0,2 \\
\cline { 2 - 3 } & Tahan 1 penyakit & Variabel ke-2 / 2/5 =0,4 \\
\cline { 2 - 3 } & Tahan 2 penyakit & Variabel ke-3 / 3/5 =0,6 \\
\cline { 2 - 3 } & Tahan 3 penyakit & Variabel ke-4 / 4/5 =0,8 \\
\cline { 2 - 3 } & $\begin{array}{l}\text { Tahan lebih dari } \\
\text { 3 penyakit }\end{array}$ & Variabel ke-5 / 5/5 =1 \\
\hline
\end{tabular}

Tabel 11. Umur Panen

\begin{tabular}{|c|c|c|}
\hline Kriteria & Range & Bobot \\
\hline \multirow{5}{*}{$\begin{array}{l}\text { Umur } \\
\text { Panen }\end{array}$} & $\begin{array}{l}\text { 100-120 Hari } \\
\text { Setelah Tanam }\end{array}$ & Variabel ke-1 / 1/5 = 0,2 \\
\hline & $\begin{array}{l}\text { 100-115 Hari } \\
\text { Setelah Tanam }\end{array}$ & Variabel ke-2 / 2/5 $=0,4$ \\
\hline & $\begin{array}{l}\text { 100-105 Hari } \\
\text { Setelah Tanam }\end{array}$ & Variabel ke-3 $/ 3 / 5=0,6$ \\
\hline & $\begin{array}{l}\text { 90-105 Hari } \\
\text { Setelah Tanam }\end{array}$ & Variabel ke-4 / 4/5 = 0,8 \\
\hline & $\begin{array}{l}\text { 90-95 Hari } \\
\text { Setelah Tanam }\end{array}$ & Variabel ke-5 / 5/5 = 1 \\
\hline
\end{tabular}

Tabel 12. Potensi Panen

\begin{tabular}{|c|l|l|}
\hline Kriteria & \multicolumn{1}{|c|}{ Range } & \multicolumn{1}{c|}{ Bobot } \\
\hline \multirow{4}{*}{$\begin{array}{c}\text { Potensi } \\
\text { Panen }\end{array}$} & $10-12$ ton/ha & Variabel ke-1 $/ 1 / 5=0,2$ \\
\cline { 2 - 3 } & $18-20$ ton/ha & Variabel ke-2 / 2/5 =0,4 \\
\cline { 2 - 3 } & $18-23$ ton/ha & Variabel ke-3 / 3/5 =0,6 \\
\cline { 2 - 3 } & $26-27$ ton/ha & Variabel ke-4 / 4/5 =0,8 \\
\cline { 2 - 3 } & $25-29$ ton/ha & Variabel ke-5 / 5/5 = 1 \\
\hline
\end{tabular}

Ditentukan berdasarkan persyaratan utama atau kriteria-kriteria diatas, selanjutnya bobot preferensi $(\mathrm{W})$ yang didapat pada perhitungan bobot menggunakan metode AHP sebagai berikut:

$\mathrm{W} 1=$ Rekomendasi Dataran $=0,063$
W2 $=$ Ketahanan Penyakit $=0,460$

$\mathrm{W} 3=$ Umur Panen $=0,388$

$\mathrm{W} 4=$ Potensi Panen $=0,089$

Dalam pemilihan bibit cabai merah unggul dengan menggunakan metode AHP dan SAW berdasarkan kriteria-kriteria diatas maka diperoleh data :

Tabel 13. Nilai dari masing-masing kriteria

\begin{tabular}{|c|c|c|c|c|c|}
\hline $\begin{array}{l}\mathrm{N} \\
\mathrm{O}\end{array}$ & $\begin{array}{l}\text { Nama } \\
\text { Bibit } \\
\text { Cabai }\end{array}$ & $\begin{array}{c}\text { Rekomen } \\
\text { dasi } \\
\text { Dataran }\end{array}$ & $\begin{array}{c}\text { Ketaha } \\
\text { nan } \\
\text { Penyak } \\
\text { it }\end{array}$ & $\begin{array}{c}\text { Umur } \\
\text { Panen } \\
\text { (HST } \\
\text { ) }\end{array}$ & $\begin{array}{c}\text { Potensi } \\
\text { Panen } \\
\text { (ton/ha) }\end{array}$ \\
\hline 1 & $\begin{array}{l}\text { KAST } \\
\text { ILO } \\
\text { F1 }\end{array}$ & $\begin{array}{l}\text { Menengah } \\
\text { - Tinggi }\end{array}$ & $\begin{array}{c}\text { Bw, } \\
\text { Phytho } \\
\text { pthora, } \\
\text { Toleran } \\
\text { FEY }\end{array}$ & $\begin{array}{l}100- \\
115\end{array}$ & $18-20$ \\
\hline 2 & $\begin{array}{l}\text { LADO } \\
\text { F1 }\end{array}$ & $\begin{array}{c}\text { Rendah - } \\
\text { Tinggi }\end{array}$ & $\mathrm{Bw}$ & $\begin{array}{c}100- \\
120\end{array}$ & $18-20$ \\
\hline 3 & $\begin{array}{l}\text { LARI } \\
\text { S F1 }\end{array}$ & $\begin{array}{c}\text { Rendah - } \\
\text { Tinggi }\end{array}$ & $\mathrm{Bw}$ & $\begin{array}{l}90- \\
105\end{array}$ & $10-12$ \\
\hline 4 & $\begin{array}{l}\text { LABA } \\
\text { F1 }\end{array}$ & $\begin{array}{c}\text { Rendah - } \\
\text { Tinggi }\end{array}$ & $\begin{array}{c}\text { Pc, Bw, } \\
\text { Fey }\end{array}$ & $\begin{array}{l}90- \\
95\end{array}$ & $18-20$ \\
\hline 5 & $\begin{array}{l}\text { LAJU } \\
\text { F1 }\end{array}$ & Rendah & $\begin{array}{c}\text { Bacteri } \\
\text { al Wilt, } \\
\text { Phytopt } \\
\text { hora } \\
\text { Capsici } \\
\text {, FEY }\end{array}$ & $90-95$ & $26-27$ \\
\hline 6 & $\begin{array}{l}\text { LENT } \\
\text { UR F1 }\end{array}$ & $\begin{array}{l}\text { Rendah - } \\
\text { Menenga } \\
\mathrm{h}\end{array}$ & $\begin{array}{c}\text { Layu } \\
\text { bakteri } \\
\text { dan } \\
\text { Phytopt } \\
\text { hora, } \\
\text { BS }\end{array}$ & $90-95$ & $25-29$ \\
\hline 7 & $\begin{array}{l}\text { PM } \\
999 \text { F1 }\end{array}$ & $\begin{array}{l}\text { Rendah - } \\
\text { Menenga } \\
\mathrm{h}\end{array}$ & $\begin{array}{c}\text { Tidak } \\
\text { tahan } \\
\text { penyaki } \\
\mathrm{t}\end{array}$ & $\begin{array}{c}100- \\
120\end{array}$ & $18-23$ \\
\hline 8 & $\begin{array}{l}\text { TARO } \\
\text { F1 }\end{array}$ & $\begin{array}{c}\text { Rendah - } \\
\text { Tinggi }\end{array}$ & Bw & $\begin{array}{l}90- \\
105\end{array}$ & $\begin{array}{ll}18 & - \\
& 2 \\
& 0\end{array}$ \\
\hline
\end{tabular}

2. Menentukan rating kecocokan setiap alternatif pada setiap kriteria. Dalam menentukan rating kecocokan maka nilai dari masing-masing kriteria dimasukkan kedalam tabel rating kecocokan yang telah disesuaikan dengan nilai dari tabel kriteria. Maka tabel rating kecocokan dapat dilihat pada tabel dibawah ini:

Tabel 14. Rating kecocokan

\begin{tabular}{|c|l|c|c|c|c|}
\hline No & $\begin{array}{c}\text { Nama } \\
\text { Bibit } \\
\text { Cabai }\end{array}$ & $\begin{array}{c}\text { Rekom } \\
\text { endasi } \\
\text { Dataran }\end{array}$ & $\begin{array}{c}\text { Ketaha } \\
\text { nan } \\
\text { Penyak } \\
\text { it }\end{array}$ & $\begin{array}{c}\text { Umur } \\
\text { Panen } \\
\text { (HST) }\end{array}$ & $\begin{array}{l}\text { Potensi } \\
\text { Panen } \\
\text { (ton/ha) }\end{array}$ \\
\hline 1 & $\begin{array}{l}\text { KASTI } \\
\text { LO F1 }\end{array}$ & 0,5 & 0,8 & 0,4 & 0,4 \\
\hline 2 & $\begin{array}{l}\text { LADO } \\
\text { F1 }\end{array}$ & 1 & 0,4 & 0,2 & 0,4 \\
\hline 3 & $\begin{array}{l}\text { LARIS } \\
\text { F1 }\end{array}$ & 1 & 0,4 & 0,8 & 0,2 \\
\hline 4 & $\begin{array}{l}\text { LABA } \\
\text { F1 }\end{array}$ & 1 & 0,8 & 1 & 0,4 \\
\hline
\end{tabular}




\begin{tabular}{|c|l|c|c|c|c|}
\hline 5 & $\begin{array}{l}\text { LAJU } \\
\text { F1 }\end{array}$ & 0,25 & 1 & 1 & 0,8 \\
\hline 6 & $\begin{array}{l}\text { LENT } \\
\text { UR F1 }\end{array}$ & 0,75 & 0,4 & 1 & 1 \\
\hline 7 & $\begin{array}{l}\text { PM 999 } \\
\text { F1 }\end{array}$ & 0,75 & 0,2 & 0,2 & 0,6 \\
\hline 8 & $\begin{array}{l}\text { TARO } \\
\text { F1 }\end{array}$ & 1 & 0,4 & 0,8 & 0,4 \\
\hline
\end{tabular}

3. Membuat matriks keputusan berdasarkan kriteria (Ci).

Nilai dari hasil tabel kecocokan kemudian dibuat kedalam bentuk matriks.

$$
X\left[\begin{array}{cccc}
0,5 & 0,8 & 0,4 & 0,4 \\
1 & 0,4 & 0,2 & 0,4 \\
1 & 0,4 & 0,8 & 0,2 \\
1 & 0,8 & 1 & 0,4 \\
0,25 & 1 & 1 & 0,8 \\
0,75 & 0,4 & 1 & 1 \\
0,75 & 0,2 & 0,2 & 0,6 \\
1 & 0,4 & 0,8 & 0,4
\end{array}\right]
$$

4. Kemudian melakukan normalisasi matriks berdasarkan persamaan yang disesuaikan dengan jenis atribut (atribut keuntungan maupun atribut biaya) sehingga diperoleh matriks ternormalisasi R. Rumus normalisasi matriks sebagai berikut: 2015)

Jika j adalah keuntungan (Benefit). (Situmorang,

$$
R i j=\left\{\frac{X i j}{M a k X i j}\right.
$$

Jika j adalah biaya (Cost)

$$
R i j=\left\{\frac{M i n X i j}{X i j}\right.
$$

$\mathrm{Vi}=$ rangking untuk setiap alternative

$\mathrm{Wj}=$ nilai bobot dari setiap kriteria

$\mathrm{Rij}=$ nilai rating kinerja ternormalisasi

$\mathrm{Ai}=$ Alternatif

Nilai Vi yang lebih besar mengindikasikan bahwa alternatif Ai lebih terpilih.

Dari perhitungan diatas diperoleh matriks R sebagai berikut:

$$
R\left[\begin{array}{cccc}
0,5 & 0,8 & 0,5 & 0,4 \\
1 & 0,4 & 1 & 0,4 \\
1 & 0,4 & 0,25 & 0,2 \\
1 & 0,8 & 0,2 & 0,4 \\
0,25 & 1 & 0,2 & 0,8 \\
0,75 & 0,4 & 0,2 & 1 \\
0,75 & 0,2 & 1 & 0,6 \\
1 & 0,4 & 0,25 & 0,4
\end{array}\right]
$$

5. Hasil akhir diperoleh dari proses perangkingan yaitu penjumlahan dari perkalian matriks ternormalisasi $\mathrm{R}$ dengan vector bobot sehingga diperoleh nilai terbesar yang dipilih sebagai alternatif terbaik (Ai) sebagi solusi.

$$
\begin{aligned}
\mathrm{V}_{1}= & (0,5 * 0,063)+(0,8 * 0,460)+ \\
& (0,5 * 0,388)+(0,4 * 0,089) \\
= & 0,315+0,368+0,194+0,0356 \\
= & 0,9126 \ldots . \mathrm{dst}
\end{aligned}
$$

Dari setiap perhitungan nilai $\mathrm{Vi}$ dari setiap alternatif maka dibuatkan tabel penentuan rangking pada tabel dibawah ini.

Tabel 15. Rangking setiap alternatif

\begin{tabular}{|c|c|l|c|c|}
\hline No & $\mathrm{Ai}$ & Nama Bibit Cabai & Nilai & Rangking \\
\hline 1 & $\mathrm{~V}_{1}$ & KASTILO F1 & 0,91 & 1 \\
\hline 2 & $\mathrm{~V}_{2}$ & LADO F1 & 0,67 & 2 \\
\hline 3 & $\mathrm{~V}_{3}$ & LARIS F1 & 0,36 & 8 \\
\hline 4 & $\mathrm{~V}_{4}$ & LABA F1 & 0,54 & 5 \\
\hline 5 & $\mathrm{~V}_{5}$ & LAJU F1 & 0,62 & 3 \\
\hline 6 & $\mathrm{~V}_{6}$ & LENTUR F1 & 0,40 & 6 \\
\hline 7 & $\mathrm{~V}_{7}$ & PM 999 F1 & 0,58 & 4 \\
\hline 8 & $\mathrm{~V}_{8}$ & TARO F1 & 0,38 & 7 \\
\hline
\end{tabular}

Dari penentuan rangking diatas, maka yang kemungkinan dipilih oleh petani adalah bibit cabai KASTILO F1, yang mendapatkan rangking pertama.

\section{Kesimpulan}

Sistem pendukung keputusan pemilihan bibit cabai merah unggul dengan menggunakan metode AHP dan SAW ini dapat membantu para petani cabai merah dalam mengambil keputusan.

Dari hasil perhitungan data menggunakan penggabungan metode AHP dan SAW didapat bibit cabai merah KASTILO F1 yang memiliki rangking nilai tertinggi dari seluruh alternatif.

\section{Daftar Pustaka}

Cholissodin, R. A. (2018). Implementasi Metode Analytic Hierarchy Process - Weighted Product Untuk Rekomendasi Hunian Ideal (Studi Kasus : Kota Malang ). J.

Pengemb. Teknol. Inf. dan Ilmu Komput. Univ. Brawijaya.

D. Walangare, R. D. (2012). Sistem Prediksi Pertandingan Sepak Bola dengan Metode AHO. Informatika.

Fitriyani, M. R. (2017). Sistem Pendukung Keputusan untuk Kenaikan Jabatan Aparatur Negara Sipil Stuktural pada Badan Kabupaten Lampung Tengan dengan Metode SAW.

Frieyadie. (2016). Dalam Sistem Pendukung Keputusan Promosi. 
Expert - Jurnal Management Sistem Informasi dan Teknologi ISSN 2088-5555

Munthafa, H. M. (2017). Penerapan Metode Analytical Hierarchy Process dalam Sistem Pendukung Keputusan Penentuan Mahasiswa Berprestasi. J. Siliwangi.

N. N. Satriani, I. C. (2018). Sistem Pendukung Keputusan Penentuan Calon Penerima Beasiswa BBP-PPA Menggunakan Metode AHP-PROMETHEE I Studi Kasus : FILKOM Universitas Brawijaya. J. Pengemb. Teknol. Inf. dan Ilmu Komput. Univ. Brawija.

P. Diah, S. D. (2018). Penerapan Metode AHP dan SAW untuk Penentuan Kenaikan Jabatan
Karyawan. JATISI (Jurnal Tek. Inform. dan Sist. Informasi).

Prajnanta, F. (2001). Agribisnis Cabai Hibrida. Jakarta: Penebar Swadaya.

Situmorang, H. (2015). Sistem Pendukung Keputusan Pemilihan Calon Peserta Olimpiade Sains Tingkat Kabupaten Langkat Pada Madrasah Aliyah Negeri (MAN) 2 Tanjung Pura Dengan Menggunakan Metode Simple Additive Weighting (SAW). J. TIMES.

Tjahjadi, N. (1991). Bertanam Cabai. Yogyakarta: Kanisius. 